\title{
QUILOMBOS E POLÍTICA (MG - SÉCULO XVIII)
}

\author{
Carlos Magno Guimarães .
}

Departamento de Sociologia e Antropologia da Faculdade de Filosofía e Ciências Humanas - UFMG

RESUMO: Através da análise de documentos da época, o artigo pretende levantar questóes sobre o caráter político dos quilombos, que foram descobertos e destruídos nas Minas Gerais do Século XVIII.

ABSTRACT: By means of a documentary analysis of the period, the author aims at raising issues on the political situation of the quilombos discovered and destroyed in Minas Gerais during the seventeenth century.

PALAVRAS-CHAVE: Escravidāo, escravismo, rebeldia escrava, quilombos, Minas Gerais.

KEY-WORDS: Slavery, proslaver system, slave rebelliousness, quilombos, Minas Gerais.

\section{Introduçäo}

O presente trabalho pretende detectar o caráter político de uma das modalidades básicas de rebeldia escrava, incorporando-se à crítica da tese, muito difundida, de que ao escravo nāo estava dada, historicamente, a possibilidade de desenvolver açoos políticas de caráter anti-escravista. Para tanto, a análise tem como objetivo os quilombos formados nas $\mathrm{Mi}$ nas Gerais durante o período colonial. Dito de outra forma, o que pretendemos é recuperar a natureza política dos quilombos em seus vários aspectos. Neste caso buscamos atingir objetivos mais específicos tais como: detectar como é que as diferentes categorias sociais participam do grande conflito senhor versus escravo, e identificar algum tipo de comportamento de quilombolas que evidencie clareza de objetivos políticos.

A importância desta questão está refletida na atual Constituição Brasileira que, em seu artigo 68 do ato das Disposições Constitucionais Transitórias, atrela a defesa da propriedade da terra das comunidades rurais negras à necessidade de provarem sua origem em antigos quilombos. Quer nos parecer que a questão política atual nos remete à necessidade de conhecimento da questão política no passado. Nosso texto será dividido em duas partes. A primeira servirá para localizarmos as duas grandes vertentes da literatura sobre escravidão no Brasil que de alguma forma tocaram na questão do escravo enquanto su- 
jeito político; na segunda parte desenvolveremos as reflexões pertinentes ao objetivo proposto. Os dados sobre a sociedade mineira colonial são extraídos de documentos que se encontram depositados na Secção Colonial do Arquivo Público Mineiro e serão identificados nas notas pela sigla SCAPM.

Gostaríamos ainda de esclarecer que o presente trabalho faz parte de um projeto maior - Projeto Quilombo - que pretende desenvolver uma análise dos quilombos na sociedade escravista mineira nos seus vários aspectos (políticos, sociológicos, etnológicos, etc). Em diferentes momentos pudemos contar com financiamento da Fundação Ford/Centro de Estudos Afro-Asiáticos, da Fundaçāo de Amparo à Pesquisa de Minas Gerais - FAPEMIG e da própria Universidade Federal de Minas Gerais. Agradecemos a estas instituiçōes a possibilidade de desenvolvimento do projeto.

\section{I}

Na vasta literatura (ALVES, 1979; MONTEIRO \& MOSCOSO, 1990; GUTIERREZ \& MONTEIRO, 1990) que trata da escravidão no Brasil, na qual se desta-cam muitas obras pelo seu inegável valor científico, e outras tantas pela falta dele, é possivel perceber claramente a existência de pelo menos duas grandes correntes, no que diz respeito ao comportamento do escravo.

Deixemos que falem os próprios autores.

Em obra que tem o sugestivo título Rebeliōes da Senzala, Clóvis Moura afirma ser

Verdade que o escravo, ao se rebelar contra a ordem que o subjuga, não possui elementos cognitivos capazes de fazê-lo um homem autoconsciente. Sua posiçāo de membro de uma classe colocada como entrave ao desenvolvimento das forças produtivas (nāo permitia a ele) ter elementos ideológicos capazes de transformá-lo na classe que, através de suas lutas, conseguiria o poder do Estado (MOURA, 1972).
A influência de um certo marxismo na citaçäo de Clóvis Moura é evidente. Mas o que pretendemos chamar a atenção é para a idéia de que o escravo está de tal forma limitado pelo sistema, que nāo tem condiçōes nem mesmo de ter consciência de sua própria realidade. Automaticamente isto o leva à "incapacidade ideológica" de articular um "movimento classista" em direção ao poder do Estado .

Em princípio dos anos 60 , a preocupação com a transição escravismo/capitalismo possibilitou o surgimento de duas obras que vieram, por um lado, ampliar o conhecimento sobre o cscravismo brasileiro e, por outro lado, reforçar a tese que denominaremos de "incapacidade política do escravo". Com As Meta. morfoses do Escravo, Octávio lanni inscreve-se no rol dos estụdiosos da escravidão no Brasil trazendo im. portante contribuiçāo para o debate sobre a tese da democracia racial. Ao analisar o movimento abolicionista no Paraná, Octávio Ianni considera que os atos do escravo que negavam a ordem escravista eram determinados

Pela necessidade individual de evadir-se da situação escrava, onde a sobrevivência reduzia-se aos mínimos físj cos, e nāo pela exigência coletiva de abolir o regime. A condição escrava é incompatível com uma. organizaçäo do comportamento neste sentido. [...] para que assumisse tal significado, seria preciso que o comportamento da coletividade cativa fosse organizado em funçāo de uma elaboração consciente da condiçāo escrava; seria necessário que se atribuísse à casta dos cativos a possibilidade de aprender, ainda que fragmentariamente, a situaçāo alienada em que se encontrava (IANN], 1962, p. 234).

Como se percebe, para $O$. Ianni o escravo estava impossibilitado de realizar uma "elaboraçáo consciente da condição escrava" já que não tinha como perceber a situaçăo alienada em que se encontrava. Também aqui se percebe a influência (do pensamento hegeliano e marxis̀ta) da teoria da alienaçāo. A outra obra surgida nesta época e também ligada ao mesmo contexto (e projeto) é Capitalismo e Escravidão 
no Brasil Meridional de Fernando Henrique Cardoso. Estudando o escravismo no Rio Grande do Sul, Fernando Henrique Cardoso reelabora e até mesmo sofistica a questāo embora, a nosso ver, continue presente o mesmo tipo de visão.

$O$ autor em questão admite duas possibilidades:

quando o escravo participava da produção em grande escala para a exportação, atuava unicamente como mão-de-obra reificada. Nesta qualidade, é óbvio que năo podia tomar consciência da sociedade como um todo nem do sentido que sua situação de dependência adquiria no contexto social: a socializaçāo parcial a que o sujeitavam, a despersonalizaçāo a que era submetido e as formas de coerçăo e controle desenvolvidas pela sociedade escravocrata tornavam o escravo incapaz de reação coordenada e de perceber criticamente sua posição.[...] Quando porém o negro participava da produção doméstica ou artesanal começava a ter possibilidade de perceber a sociedade como um todo e de aprender o sentido đa situação do escravo e do negro na totalidade (CARDOSO, 1977, pp. 217-218).

Mas, como o setor exportador da economia é que regulava a dinâmica da sociedade global, também ao escravo doméstico e ao artesão estava vedada a possibilidade de "pôr em xeque a totalidade do sistema escravista". Apenas na fase de desagregação do sistema é que "o escravo urbano pôde alcançar, embora precariamente, algum grau de compreensão da sociedade escravista”. Neste momento

a açāo dos escravos começava a voltar-se para a totalidade do sistema que já aparecia como um estado de violência. $O$ sentimento real e profundo da escravidão teria, contudo, de pemanecer inacessível à consciência escrava (CARDOSO, 1977, p. 219).

Um elemento importante a ser considerado é que, geralmente quando se considera a possibilidade do escravo tornar-se consciente de sua realidade (ou tornar-se parcialmente desalienado), esta possibilidade está sempre atrelada a uma vanguarda não escrava do movimento abolicionista. É a idéia de que a classe escrava não pode produzir uma consciência da realidade por si mesma. Isto só seria possível com a interferência de agentes externos a ela.

Por outro lado, percebe-se um certo desencanto com a classe escrava, na medida que se atribui a ela uma incapacidade de desenvolver movimentos revolucionários nos moldes da burguesia e do proletariado europeus.

Em estudo sobre o Quilombo de Palmares, Décio Freitas diz que

no caso das formações sociais escravistas, as da Antigüidade ou as dos tempos modemos, não foi o processo de contradiçōes intemas o fator deteminante da mudança; a mudança foi provocada primordialmente por fatores externos [mesmo porque] a trágica contradiçāo que pesava șobre as rebeliōes escravas consistia em que, por um lado, não podiam triunfar a menos que ganhassem a adesão de alguma categoria social importante e, por outro lado, esta possibilidade estava objetivamente excluída nos marcos da sociedade escravista (FREITAS, 1978, p. 188).

Ainda é este mesmo autor que, na apresentaçāo de um estudo sobre rebeliōes escravas cuja primeira edição é de 1976, afirma que

em toda parte, os protestos escravos sempre tiveram lugar no quadro rural. Entre nós, expressaram-se através do conhecido quilombo. Os escravos se revoltavam e estabeleciam comunidades em lugares de difícil acesso. Depois, vivendo à base de uma economia de subsistência, resistiam às tentativas de reescravizaçāo e ajudavam outros escravos a se libertarem do cativeiro. Essa massa de escravos rurais nunca tentou, entretanto libertar-se coletivamente por meio de uma insurreiçăo geral. Nem se afigurava possivel uma tal insurreição. Isolados pelas imensas disṭ̂ncias que separavam um engenho do outro, nāo tinham os escravos como organizar e articular um movimento coletivo: Os seus protestos eram realmente, mais existenciais que políticos (FREITAS, 1976, p. 9).

Infelizmente as citações são grandes, mas necessárias.

No final de seu livro, Décio Freitas conclui que as. rebeliōes escravas ocorridas na Bahia no século passado "tinhtiam por objetivo a derrubada do sistema 
escravista" e, por causa disto "revestiam um cunho indubitavelmente revolucionário". Todavia "pertenciam às insurreiçôes sociais do tipo arcaico, não do tipo modernizante. Eram insurreições anti-escravistas e nada mais do que isso" (FREITAS, 1976, p. 99).

O fecho da citaçāo é emblemático do preconceito eurocêntrico que, de certa forma, caracteriza esta linha de análise.

Ao se tomar como parâmetro a perspectiva que o marxismo, enquanto projeto político, propôs para o proletariado, o escravo acaba reduzido a uma condição de "classe de segunda categoria", incapaz de atingir uma visāo da realidade e de articular movimentos de caráter político que apresentassem uma alternativa à estrutura de dominação (da sociedade escravista).

Quer nos parecer, entretanto, que esta é apenas uma das vertentes do marxismo vulgar. A teoria nāo é homogênea, principalmente em se tratando de um projeto político.

Enfim, as décadas de 60 e 70 delimitam o contexto no qual a tese da "incapacidade política do escravo" apresenta sua maior vitalidade, o que nos levou a aderir a ela ainda no princípio dos anos 80 (GUIMARÃES, 1983). Os estudos que surgiram principalmente a partir da metade desta década provocaram uma mudança radical quanto a esta questão.

Caracterizada por forte influência da denominada Nova História, bem como por uma expressiva dose de anti-marxismo, consolidou-se a perspectiva de recusar a idéia do escravo incapaz e absolutamente submetido. Desloca-se o eixo da discussāo. Ao invés da contradição entre opressão e resistência, privilegia-se a negociação e o consenso. $O$ risco de cair no extremo oposto existe.

Em alentado estudo sobre a escravidāo na região de Campos dos Goitacazes, Sílvia Lara dedica um capítulo à questăo da reificaçâo do escravo. Após levantamento de situaçóes onde o escravo aparece em posiçāo de "negociação" com seu senhor, a autora conclui que a tradicional afimação sobre a reificaçăo do escravo deve ser repensada em outros termos que não os da própria afirmação. Para compreender tais situaçöes, não basta simplesmente constatarmos que os escravos eram, ali e num determinado momento, coisa e, depois e acolá, pessoa (LARA, 1988, p. 352).

Referindo-se à obra de Fernando Henrique Cardoso citada anteriormente, Sílvia Lara afirma que

tais concepções, ao salientarem coisificação e a alienação do escravo, restringem-lhe a humanidade à sua ação criminosa, a açōes de resistência explícita, como a fuga e o quilombo, ou a iniciativas senhoriais de ensinar oficios ao trabalhar cativo. Postas nestes termos, essa caracterização da figura do escravo anula a possibilidade de entender que os escravos eram seres que agenciavam suas vidas enquanto escravos, resistindo e se acomodando, e que a relaçāo senhor-escravo era fruto dessa dinâmica, entre esses dois pólos, e não uma construçāo imposta de cima para baixo, unicamente pela vontade senhorial (LARA, 1988, p. 353).

O choque entre as duas visões nāo podia ser mais evidente.

Prossigamos com esta corrente.

Um dos pesquisadores que tem se destacado na análise de rebeldia escrava é João José Reis, autor de estudos sobre revoltas escravas ocorridas na Bahia no século passado. Em artigo no qual faz uma brilhante revisão das teses sobre aquelas rebeliōes (de escravos malês), J. J. Reis afirma:

a análise de Clóvis Moura melhora de um trabalho para outro, mantendo-se entretanto alguns problemas de interpretaçāo. É deveras esquemática, e historicamente incorreta, a proposição de que escravos não podem tomar o poder, como se aquilo que aconteceu, aconteceu porque assim estava escrito no Livro Sagrado das Estruturas. Ora, dadas determinadas circunstâncias históricas os escravos podem destruir a escravidão, como ocorreu no Haiti (REIS, 1988, pp.107-108).

Mais claro não poderia ser este posicionamento diante da tese da incapacidade política do escravo. Mas, J. J. Reis prossegue: 
o espaço de trabalho africano na cidade era um lugar privilegiado de elaboração cultural e política, ali onde se materializava a exploraçāo escravista também produziam símbolos de rebeldia e projetos de uma vida independente do senhor branco e seus aliados (REIS, 1988, p. 135).

Em obra mais alentada onde trata especificamente do levante dos escravos malês de 1835 , J. J. Reis reproduz as palavras do presidente da província baiana sobre o escravos que participaram do movimento: "é inegável que eles tinham um fim político, porquanto não consta que eles roubassem alguma casa nem que matassem aos senhores ocultamente" (REIS, 1986, p.105).

O intuito de captar a expressão política dos movimentos articulados pelos escravos baianos do século XIX é evidente em J. J. Reis, para quem a "rebeliāo de 1835 demonstra que os malês foram além da subversão simbólica. A partir de um determinado momento eles começaram a estruturar politicamente a proposta rebelde" (REIS, 1986, p. 138).

Nāo é nosso objetivo fazer uma exposiçāo exaustiva dos diferentes autores de cada corrente, mesmo porque isto escapa totalmente à orientação do trabalho. Vamos concluir esta parte com a referência a uma obra, nāo tão expressiva quanto as citadas anteriormente, mas válida para nossos intentos. Trata-se de Visões da liberdade de Sidney Chalhoub (CHALHOUB, 1990).

Numa tentativa pretensiosa de acabar de vez com o que denomina de "teoria do escravo-coisa", Chalhoub volta-se contra Perdigāo Malheiro, Fernando Henrique Cardoso e Jacob Gorender. Mas, se por um lado consegue identificar pontos críticos (e criticáveis) nas obras dos referidos autores, Chalhoub nāo consegue ir além, mesmo porque estabelece uma igualdade entre o que denominamos de "tese da incapacidade política do escravo" com o que ele denomina de "teoria do escravo-coisa". O raciocínio deste autor é de lógica formal primária: se a incapacidade política do escravo não existiu, a teoria do escra- vo-coisa perde a sua razāo de ser. É necessário admitir que a crítica de Chalhoub é pertinente em alguns aspectos, mas o resultado final nos parece desastroso. A reificação do escravo no plano econômico é diferente de sua expressão política. Ao igualar as duas coisas Chalhoub destruiu a possibilidade de avançar sua crítica.

Para Chalhoub, o escravo que negocia algumas das suas condiçōes de existência estaria também negando o seu ser-coisa. Tal ponto de vista é um equívoco se levarmos em conta a alienação em uma perspectiva totalizante. Embora possa negociar, o escravo nāo deixa de ser escravo: o que significa dizer que ele nāo deixa de ser coisa. Por outro lado, o fato do indivíduo ser escravo nāo impede que ele possa ter, o tempo todo, atitudes políticas' de negação da ordem escravista. Esta é a expressão da contradição existente em cada escravo: ser ao mesmo tempo coisa e sujeito histórico. $O$ processo de reificação/alienação não se dá apenas em um ou outro nível. Aqui cabe uma crítica à posiçāo de Sílvia Lara. A citação desta autora que reproduzimos anteriormente traz uma visão equivocada da dialética. Não se trata de ser uma coisa aqui agora e uma pessoa acolá, em seguida. Trata-se de ser coisa e pessoa ao mesmo tempo, tanto aqui como acolá. A questāo chave é detectar em cada momento qual é o caráter prevalente.

De qualquer maneira, tanto o trabalho de S. Lara quanto o de $\mathrm{S}$. Chalhoub são expressivos da corrente que vê o escravo nāo como sujeito totalmente submetido mas, enquanto sujeito que luta por interesses e obtém vitórias no jogo que (por envolver relações de negociação e conflito entre classes) estamos denominando de político. Dentre as duas correntes, que pretendemos ter evidenciado, nosso trabalho apontapara uma compreensāo dos quilombos enquanto fenômenos portadores de um caráter político que necessita ser evidenciado. Passemos, pois, aos quilombos. 
II

O primeiro aspecto a ser elucidado e que diz respeito à questão política propriamente dita, parecenos ser a necessidade de definir (mesmo que de forma sucinta) o universo teórico dentro do qual pretendemos transitar.

Valemo-nos de N. Bobbio que em seu Dicionário de Política (BOBBlO,1992, pp. 954-962) levanta alguns pontos fundamentais para nossa reflexăo. Ao desenvolver a tipologia clássica das formas de poder, Bobbio faz a primeira referência que nos interessa ao afirmar que o "conceito de política, entendida como forma de atividade ou de práxis humana, está estreitamente ligado ao de poder". A natureza do poder diz respeito ao "domínio sobre outros homens", o que significa dizer uma imposição de vontade e uma determinação de comportamento. Essa relação de poder pode se expressar de diferentes maneiras: como relação entre governantes e govcrnados, soberanos e súditos, Estados e cidadãos, entre autoridade c obediência, etc. "Há várias formas de poder do homem sobre o homem; o poder político é apenas uma delas".

Ao estabelecer a tipologia moderna das formas de poder, Bobbio nos dá outros elementos. Começa por distinguir três grandes classes: "o poder econômico, o poder ideológico e o poder político". O poder econômico, cuja base se encontra "na posse de certos bens, necessários ou considerados como tais, numa situação de escassez", o poder ideológico baseado na influência das idéias e finalmente o poder polítjco baseado

na posse dos instrumentos mediante os quais se exerce a. força política ... é o poder coator no sentido mais estrito da palavra. Todas essas três formas de poder fundamentam e mantêm uma sociedade de desiguais (BOBB1O, 1992, pp. 954-962).

Nāo poderíamos deixar de acrescentar aqui que esta sociedade de desiguais pode ser, por exemplo, a sociedade escravista mineira colonial dividida (pelo menos em seus extremos) entre senhores e escravos. Bem, se a tipologia de Bobbio pode nos ser útil até aqui, julgamos necessário acrescentar elementos que nāo se encontram nela. Destaca-se, a nosso ver, o fato de que na totalidade social as várias formas de poder se encontram entrelaçadas $\mathrm{e} \mathrm{cm}$ relaçōes de determinaçāo. A articulaçāo entre as instâncias da vida social se reflete na existência da própria estrutura de poder vigente na sociedade.

Assim, na sociedade escravista, o domínio do senhor sobre o escravo se constitui no eixo fundamental de exercício do poder, tanto na esfera econômica quanto na política e ideológica. Este eixo, na realidade, vai constituir um ponto central, em torno do qual se articula toda a estrutura de poder e se desenvolve o conflito, que acabará por dar a tônica da dinâmica social.

É o que parece indicar a análise dos quilombos por nós desenvolvida. Vamos a ela.

O ponto que trataremos a seguir diz respeito às diferentes catcgorias sociais e sua participação no contexto da luta entre senhores e escravos. Luta que se expressa na existência dos quilombos.

Como ponto de partida vamos nos utilizar do conceito de classe social da maneira como a definiu Lenin. É forçoso reconhecer que o conceito leninista é limitado e expressa a categoria numa perspectiva fundamentalmente econômica ; entretanto, cabe para nossos objetivos. Segundo Lenin classes sāo

grandes grupos de pessoas que se diferenciam entre si pelo seu lugar num sistema de produção social historicamente determinado, pela sua relaçāo (as mais das vezes fixada e formulada nas leis) com os meios de produção, pelo seu papel na organização social do trabalho e conseqüentemente, pelo modo de obtenção e pelas dimensōes da parte da riqueza social de que dispõem. As classes săo grupos de pessoas, um dos quais pode apropriar-se do trabaiho do outro graças ao fato de ocupar um lugar diferente num regime determinado de economia social (LENINE, 1980, p. 150). 
Esta definiçāo nos permite identificar tanto o escravo quanto os proprietários de escravos como integrantes de classes distintas. Arriscamos ainda a admitir o forro enquanto classe, cuja existência apresenta a peculiaridade de ser originária da classe escrava. Mas, o que aparentemente é simples neste esquema, se torna extremamente complicado quando nos remetemos à realidade. Se ser escravo é ter uma posição clara na estrutura social, ser senhor de escravos já nāo é tão claro. Os senhores de escravos tanto poderiam ser livres quanto poderiam ser forros e até mesmo escravos. À medida que desdobramos cada categoria nas suas especificidades, a complexidade da trama social e a dificuldade de apreendê-la se tornam mais evidentes.

O nosso ponto de partida é a constatação de que os quilombos configuram (e estão no centro de) uma realidade conflituosa da qual participam diferentes senāo todas - categorias sociais. Esta realidade nada mais é que um conflito entre senhores e escravos, o que nos permite atribuir-lhe um caráter político (MARX, 1976, p. 164).

A grande questão é desvendar como cada u uma das categorias sociais (escravos, senhores, forros, etc.) participam deste grande conflito. Dito de outra forma, qual é o posicionamento político de cada categoria diante do conflito que, de certa forma, atinge toda a sociedade? Começaremos pela classe escrava.

Como é que os escravos se posicionam diante dos quilombos, considerando que a maior parte dos escravos não foge?

Em 1714, o governador D. Braz Balthazar proibiu o uso de armas nas Minas, exceto para senhores que fossem viajar. Estes poderiam levar escravos armados para se defenderem nas estradas (SCAPM, cód. 09, p. $10 \mathrm{v}$.). Apenas lembramos que uma das ameaças a que os viajantes estavam sujeitos vinha da parte dos quilombolas.

Em 1722, o governador D. Lourenço de Almeida concedeu patente de sargento-mor de ordenança a
João Reis Cortes, que havia participado de campanhas contra quilombos, utilizando como atacantes seus próprios escravos (SCAPM, cód. 21, p. 89 e v.). Dez anos depois, em 1732, o capitão dos dragōes José de Morais Cabral sugeria em carta a D. Lourenço que a Fazenda Real comprasse vinte e quatro escravos que, armados, seriam utilizados em substituição aos capitães-do-mato na Comarca do Serro Frịo (SCAPM, cód. 27, p. 114).

Em 1736, foi a vez de Bento Ferraz de Lima receber patente de capitão-mor das Catas Altas por ter cumprido bem a tarefa de destruir quilombos no morro do Caraça, "no que dispendeu considerável fazenda por levar muitos escravos armados" (SCAPM, cód. 49 , p. 69 v. a 71).

Em todos os casos citados, temos uma situaçāo em que os senhores armam seus escravos e os utilizam contra quilombolas. São escravos que, no conflito entre senhores e escravos, lutam ao lado dos senhores.

É evidente que uma explicação para isto pode ser o fato destes escravos serem obrigados por seus senhores. Mas não é tâo fácil entender por que, estando armados, estes escravos não se voltavam contra os seus senhores.

Se participar da tropa sob comando do senhor pode ser uma situaçāo que pode explicar o comportamento destes escravos, tal nāo se dá quando o escravo age sozinho, ou fora da órbita do senhor.

Em 17 de Janeiro de 1731, o "preto escravo" Amaro de Queiroz, propriedade de José de Queiroz, recebeu patente de capitão-do-mato para atuar no distrito de Antonio Pereira, termo da Vila do Carmo (SCAPM, cód. 34, p. 20 e v.). Domingos Moreira de Azevedo, crioulo escravo de Andrá Álvares de Azevedo, em 5 de novembro de 1760 recebeu patente para atuar na área de Piracicaba e do Caraça (SCAPM, cód. 114, p. 167 e v.). E, em dezembro de 1779, foi confirmada patente a José Ferreira, pardo escravo do capităo Antonio João Belas (SCAPM, çód. 18217, p. 130). 
Nestes três últimos casos citados, a autonomia de cada um dos escravos é muito grande. Não há a presença de seus senhores no momento em que atuam profissionalmente e, no entanto, eles não fogem e ainda atuam como peças importantes na manutençāo do sistema que os coloca na condição de escravos.

Bem, se por um lado temos escravos que lutam, literalmente, em defesa do escravismo e ao que tudo indica seu número foi grande, a posiçāo contrária pode ter sido a mais comum.

Uma reclamaçāo constante das autoridades coloniais se relacionava à rede de informaçōes criada pelos quilombolas, e que os avisava sempre da movimentação das tropas opressoras. Esta rede agia a partir das próprias senzalas.

Em 1759, Bartolomeu Bueno do Prado, em sua campanha no Campo Grande encontrou um grande quilombo despovoado pelo fato dos quilombolas terem tido conhecimento com antecedência da organização e deslocamento da tropa (SCAPM, cód. 123, p. $103 \mathrm{e} \mathrm{v.)}$.

Em 1769, o conde de Valadares escreveu ao capitāo auxiliar Manoel Rodrigues da Costa para que este fizesse averiguaçōes na "fazenda Azevedo como em outras das mais fazendas" onde se suspeitasse que os escravos passavam informaçōes para quilombolas ou thes davam guarida (SCAPM, cód. 165, p. 127 v.).

Em 25 de fevereiro de 1773, o comandante Manoel Gouvea escreveu ao capitāo-mor Liberato José Cordeiro informando que

por notícias certas que tinha de haverem negros fugidos no sertão de Crumatahy fora à roça de Francisca Antonia e que achando que os escravos desta falavam e comunicavam aqueles, intentar dar buscas nas senzalas dos seus escravos, os quais saindo armados com armas defesas the embaraçou a diligência chegando o seu arrojo a virem no provocando até o rancho que distamais de meia légua de Domingos de tal (SCAPM, cód. 199, p. 13).

Um requerimento do capitāo Elias Antonio da Silva de 1792, no qual solicita portaria que o autori- zasse a atacar quilombos, traz como argumento o fato do requerente ter, naquele momento, cinco escravos que andavam fugidos $e$

por mais diligências e tocaias ou negaças que lhes tem feito nâo é possivel aprendê-los pela razāo de se refugiarem e acoutarem se em umas poucas de fazendas que é constante servem de coito aos negros que fogem de seus senhores e que os escravos das mesmas fazendas thes facilitam o dito coito e o que mais é também alguns donos das mencionadas fazendas em gravíssimo prejuizo do particular e do bem comum (SCAPM, cód. 260, p. 16 v. e 17).

No ano de 1795, o fazendeiro Marcelino da Costa Golçalves enviou correspondencia ao governador das Minas contando que

sendo roubado com vilipêndio de sua pessoa pelos negros calhambolas no dia 24 de janeiro, agora tem notícia que os ditos negros do mato vieram acompanhados com outros das fazendas vizinhas que andavam roçando para feijāo do que persuade o suplicante pelas foices que traziam nas māos quando o assaltaram, talvez com o projeto de repar. tirem o roubo que não foi pequeno, e porque sendo assim algumas coisas ainda poderāo aparecer nas senzalas dos ditos escravos, aqueles que o suplicante desconfia pela aliança que costumam ter com os do mato, com quem repartem os mantimentos dos paíris de seus senhores ou ainda em casas de suas amasias acostumadas a darem coito e favoriá-los (SCAPM, cód. 260, p. 44 v. e 45).

Os documentos acima citados parecem-nos suficientes para exemplificar a situaçăo que descrevemos. Se uma parte dos escravos foge, defende a preservação do sistema escravista, outra parcela se posiciona claramente, e às vezes acintosamente, ao lado dos quilombolas, prestando-lhes não só ajuda material, informaçōes e até mesmo participando de suas empreitadas de saques. Do exposto até aqui, deduzimos que o conflito entre senhores e escravos, no seu desenvolvimento, por um lado gera os quilombos e por outro provoca uma ruptura no interior da própria classe escrava, fazendo com que uma parte dela lute contra os senhores e a outra lute a favor deles. 
Passemos à atuação dos forros.

O primeiro dado importante está expresso no número de forros que ingressa na profissão de homensdo-mato, cujo objetivo é a recaptura de escravos fugidos e destruição de quilombos. De um total de 467 patentes de homem-do-mato levantadas, quase quinze por cento foram concedidas a forros (GUIMA. RÄES, 1983, p. 120 e segs.). A utilização do forro em posições chaves pelo sistema escravista foi percebida em várias circunstâncias por outros estudiosos (QUEIROZ, 1977, p. 53; IANNI, 1962, p. 61 e 146; BOXER, 1969, pp. 190-191). Acresce-se a este dado o fato de que grande número de forros acabou por se tornar proprietário de escravos, o que os colocava na condição de defenderem seus interesses lutando pela preservação do sistema. Para citar apenas duas cifras, segundo Francisco Vidal Luna, no Serro Frio em 1738, dos 1744 proprietários de escravos, 387 eram forros; e na freguesia das Congonhas do Sabará em 1771, de um total de 235 proprietários de escravos, 51 eram forros (LUMA, 1981, p. 75 e 92).

Dando ao forro a possibilidade de se tornar senhor de escravos, o escravismo adquiria uma maior capacidade de resistência às pressōes da classe escrava. Dito de outra forma, uma parte dos antigos escravos da cooptada para lutar em defesa do escravismo.

Mas, se uma parte dos forros defende o sistema, outra parte caminha na direção oposta.

O primeiro documento nos remete ao conde de Assumar que, em 1719, acusava os forros de assistirem "o muitas vezes com ouro, mantimentos, pólvora e chumbo aos quilombos de negros fụgidos".

Continuando, Assumar investe contra as forras proprietárias de vendas, pois, segundo ele; "nas casas destas depravadas [os quilombolas] fazem os seus ajuntamentos e tomam as suas resoluçōes para insultar e desinquietar com o sumo perigo os brancos nas suas fazendas" (SCAPM, cód. 04, pp. 740748).
Em 1732, em carta enviada ao conde das Galveas, na época governador das Minas, El Rei pede parecer sobre determinadas medidas a serem tomadas contra as mesmas negras forras, proprietárias de vendas, sobre as quais pesavam as acusaçōes de prostituição e de nas suas casas virem

prover-se do necessário os negros salteadores dos quilombos, tomando notícia das pessoas a que hão de roubar e as partes onde lhes convém entrar e sair, o que tudo fazem mais facilmente achando ajuda e agasalho'nestas negras que assistem nas vendas (SCAPM, cód. 35, doc. 110).

Em 1736, é a vez do governador Gomes Freire de Andrade emitir opinião a respeito dos problemas. Considera que nāo deve haver deslocamentos de tropas de ordenanças em socorro à Marinha (em uma circunstância específica) pois elas eram necessárias contra

os inimigos internos quais se podem considerar em semeIhante ocasiāo não só os negros fugidos que costumam saltear os caminhos, mas os mulatos forros, mamelucos $\mathrm{e}$ ainda os próprios escravos (SCAPM, cód. 44, p. 129 v. e 130).

Em julho deste mesmo ano, os "moradores da Freguesia de Săo Sebastiāo" fizeram um pedido ao governador Martinho de Mendonça. para que pudessem atacar "um quilombo de negros e fazer buscas nas casas dos forros e açoitar os delinqüientes". (SCAPM, cód. 59, p. 2)

Em janeiro do ano seguinte, este governador, atendendo à petiçāo do capitāo-do-mato Francisco Soares, determinou que "nāo se impeça ao suplicante entrar nas tavernas e casas de negros e mulatos" forros quando estiverem em diligência a procura de fugitivos (SCAPM, cód. 59, p. 11 v.)

Em 1764, é a vez do governador Luis Diogo Lobo da Silva tentar pôr sob controle os escravos e forros das Minas. Em extenso bando, onde recorre a leis a partir de 1719 , proíbe que as negras de tabuleiro (tan- 
to forras quanto escravas) possam negociar seus produtos em áreas onde seja possivel o extravio de ouro ou negócios com quilombolas (SCAPM, cód. 50, pp. $90-96$ v.)

As evidências sāo suficientes. Da mesma forma que os escravos, também os forros, no seu conjunto, são afetados pelo conflito senhor versus escravo, que os leva a se posicionarem ao lado de um ou de outro. As posiçōes não deixam dúvidas: ou se combate o escravo rebelde, ou se faz aliança com ele.

Após termos tratado dos escravos e dos forros, não poderíamos deixar de lado os senhores de escravos, que estavam na categoria de homens livres.

Pelo menos um caso levantado merece referência, muito mais pelo seu caráter de exceçāo que de tendência geral.

Tendo sido efetuada uma batida na casa do Alferes Antonio Muniz de Medeiros no ano de 1781, constatou-se a existência de "uma venda oculta aonde os negros fugidos e garimpeiros se iam prover de mantimentos".

O alferes alegou que os produtos cram para vender para seus próprios escravos, embora na região todos soubessem que ele vendia

só aos negros fugidos e garimpeiros, é tanto assim que nunca deixo de haver quilombos ao pé de sua casa, e com tan. ta liberdade que até as suas escravas iam de dia ao quilombo conversar com os negros fugidos (SCAPM, c6d. 224, pp. 21.5-2.17 v.).

O que é excepcional, neste caso, não é um indivíduo livre dar cobertura a quilombolas, mas o fato de ser este indivíduo um proprietário de escravos. É uma contradiçāo, no limite, do sistema escravista.

É evidente que estes senhores de escravos faziam alianças com quilombolas, na medida que seus próprios escravos nāo tinham fugido para quilombos, e ainda poderiam auferir algum lucro como no caso do alferes Antonio Muniz.
A raridade deste tipo de comportamento nos leva a concluir que, se por um lado as classes subalternas (como escravos e forros) estavam divididas com relação ao conflito senhor versus escravo, por outro lado a sobrevivência do sistema exigia um mínimo de coesão dos proprietários de escravos.

Como última parte deste trabalho, gostariamos de tratar da atuaçăo de certo número de escravos que tiveram, a nosso ver, papel destacado na existência dos quilombos enquanto fenômeno de natureza política.

Sāo escravos que se projetam como líderes e executam uma tarefa fundamental: convencer outros escravos a fugirem, servir de guia para estes novos quilombolas e fazer a articulação entre vários quilombos.

Em dezembro de 1759, o governador José Antonio Freire de Andrade escreveu aos juizes e oficiais da Câmara de São João Del Rei sobre um quilombola preso no Campo Grande. Para justificar o envio do dito quilombola para o Rio de Janeiro, o governador argumentava que

o capitão Antonio Francisco França me tem segurado por duas ou três vezes que em o dito negro se soltando, não ficará negro algum nesta capitania que ele nāo torne a conduzir para os quilombos do Campo Grande (SCAPM, cód. 123 , p. 130 v.).

O Quilombo do Cascalho, destruído em 1760 no governo de José Antonio Freire de Andrade, recebeu este nome porque seu líder era assim denominado. Este quilombola foi preso quando havia "saído dele fazer gente para levar para dentro" (SCAPM, cód. 130 , p. 50 e v.).

Em 1771, o conde de Valadares recomendava ao capitāo Manoel Furtado Leite de Mendonça "para evitar terríveis danos que seguem do negros fugidos para prender estes $e$ um lote que anda convidando aos que estão quietos em casa de seus senhores". (SCAPM, cód. 171, p. 8 v. e 9). 
Dez anos depois, em 1781, de Paracatú escrevia Antonio José Dias Coelho ao governador informando a inquietação em que.se encontravam os moradores locais com relaçāo aos quilombolas, dentre outros motivos porque eles chegavam

a passear de noite pela vizinhança do Arraial, e entrando dentro cautelosamente, para persuadir à fugida as negras da casa de seus senhores... é fácil de crer que dentro do Arraial, haverá negro que tenha inteligência com os calhambolas, para avisar as espias do projeto dos capitāes-do-mato e por isso quando estes vão fica frustrada a diligência (SCAPM, cód. 223, p. 7 v. e 8 ).

No mesmo ano de 1781 , os moradores do distrito da Ressaca, termo da Vila de São José, reclamavam dos "negros fugidos que não somente desencaminhava os seus escravos como tão bem lhe furtam as suas criaçōes e mantimentos" (SCAPM, cód. 231, p. $41 \mathrm{e}$.).

Finalmente, digno de nota é o caso citado em requerimento do capitāo Elias Antonio da Silva, também morador no termo da Vila de São José. Refere-se a

um dos escravos das ditas fazendas [que] é costumado e atualmente dá asilo a escravos errones, socorrendo os de todo necessário com tanto escândalo e animosidade que não falta quem diga que ele é ciente e noticiado de qualquer quilombo ainda existente na distância de 30 ou 40 léguas (SCAPM, cód. 260, p. 16 v. e 17).

Sem dúvida alguma, o trabalho de convencimento executado por estes escravos deve ser visto enquanto atividade voltada para um objetivo específico: viabilizar a instalação e crescimento dos quilombos. Se entendemos os quilombos enquanto manifestaçāo de caráter político, é evidente o caráter político também destas atividades.

Por outro lado, é necessário considerar que estes escravos tinham uma consciência precisa de sua re- alidade e da maneira como deveriam enfrentá-la. É nesta medida que nos parece viável a percepção do quilombo enquanto a viabilização de um projeto político.

\section{Conclusāo}

Dos pontos abordados consideramos válidas algumas conclusões:

- em primeiro lugar, a necessidade de superaçāo da tese que prega a incapacidade política do escravo; - em segundo lugar, a percepção do quilombo enquanto uma modalidade de existência do campesinato na sociedade escravista mineira colonial que constitui o universo abordado. Nāo descartamos evidentemente a possibilidade de aplicação do esquema analítico a outras épocas e sociedades;

- em terceiro lugar, a necessidade de percepção deste campesinato não só na sua dimensão econômica (visão mais imediatista), mas também na sua dimensảo política, enquanto agente coletivo no jogo das contradiçōes que dão a tônica à dinâmica social;

- em quarto lugar, o fato do quilombo enquanto expressão da luta de classes, entre senhores e escravos, ser um ponto em torno do qual se dividem os escravos e forros;

- em quinto lugar, a inegável coesão da classe proprietária de escravos no seu posicionamento diante do referido conflito;

- finalmente, a possibilidade de percepção do quilombo não só enquanto fenômeno, mas principalmente enquanto projeto político que evidencia estratégias de realização por parte de seus membros.

Enfim, pensar o quilombo nas suas várias nuances pode nos permitir compreender melhor sua dinâmica e sua inserção na sociedade escravista. 


\section{Bibliografia}

ALVES, Henrique L. Bibliografio Afro-brasileira: Estudos sobre o Negro. Rio de Janeiro, Cátedra/lNL, 1979.

BASTIDE, Roger. Estudos Afro-brasileiros. São Paulo, Perspectiva, 1973.

BOBBIO, N.; MATTEUCCI, N. \& PASQUINHO, G. Dicionário de Politica. Brasilia, Edunb, 1992.

BOXER, Charles. Idade de Ouro do Brasil. São Paulo, Nacional, 1969.

CARDOSO, Ciro F. S. A Afro-América: a cscravidão no Nova Mundo. São Paulo, Brnsiliense, 1982.

. Agricultura, Escravidão c Capitalismo. Petrópolis, Vozes, 1979.

. Escravo ou Camponĉs? São Paulo, Brasiliense, 1987.

CARDOSO, Fernando H. Capitalismo e Escravidão no Brasil Meridional. Rio de Janeiro, Paz e Terra, 1977.

CHALhOUB, Sidney. Visóes da Liberdade. Sāo Paulo, Companhia das Letras, 1990.

CONSTITUIÇÃO DA REPÚBLICA FEDERATIVA DO BRASIL. São Paulo, Saraiva, 1992.

FORTES, M. \& EVANS-PRITCHARD, E. E. Sistemas Politicos Africanos. Lisboa, Fundaçāo C. Gulbenkian, 1981.

FREITAS, Décio. Palmares: a guerra dos cscravos. Rio de Janeiro, Graal, 1978.

A revolta dos Malês: insurreiçōes escravas. Porto Alegre, Movimento, 1976.

GOUlART, J. Alipio. Da Fuga ao Suicidio. Rio de Janeiro, Conquista, 1972.

Da Palmatória ao Pattbulo. Rio de Janeiro, Conquista, 1971.

GUIMARÃES, Carlos M. "Esclavitud, Rebeldia y Arte". Contribucioncs al estudio del artc rupcstre sudamericano $n^{2}$ 3. La Paz, SIARB, 1992.

. “I quilombos brasiliani e il mito della dolce schiavitú". In: Movimento Opcrário c socialista $n^{2} 2$. Gênova, Centro Ligure di Storia Sociale, 1988, Ano XI (Nuova Serie).

"Quilombos e brecha camponesa". Rcvista do Dcpartamento de História $n^{\prime} 8$. Belo Horizonte, Fafich/ UFMG, 1989.

. Uma Ncgaçāo da Ordem Escravista: quilombos cm Minas Gerais no século XVIII. Belo Horizonte, Fafich/UFMG, 1983, mimeo.
\& LANNA, A. L. D. “Arqueologia de quilombos em Minas Gerais". Pcsquisas: Antropologia n" 31 . São Leopoldo, Instituto Anchietano de Pesquisas, 1980.

GUIMARÄES, Carlos M. \& REIS, L. M. "Agricultura e escravidāo em Minas Gerais (1700/1750)" Revista do Dcpartamento de História $n^{* 2}$. Belo Horizonte, Fafich/ UFMG, 1986.

. et alli. “O quilombo do Ambrósio: lenda, docu. mentos e arqueologia". Estudos Ibero-Amcricanos XVI (1, 2) 31. Porto Alegre, PUCRS, 1990.

GUTIÉRREZ, Horácio \& MONTEIRO, J. M. A Escravidão na América Latina c Caribe. São Paulo, Unesp/CELA, 1990.

IANNI, Octávio. As Metamorfoses do Escravo. Sāo Paulo, Difel, 1962.

LARA, Sísvia H. Campos da Violência. Rio de Janciro, Paz e Terra, 1988.

LENINE, V. I. "Uma Grande Iniciativa". In: Obras Escolhidas vol. 3. Sāo Paulo, Alfa-Ômega, 1980.

LUNA, Francisco Vidal. Minas Gerais: escravos $c$ senhores. São Paulo, IPE, 1981.

MANNING, Patrick. "Escravidāo e mudança social na África". Novos Estudos n" 21. São Paulo, Cebrap, 1988.

MARX, Karl. Miseria da Filosofia. Sāo Paulo, Grijalbo, 1976.

MONTEIRO, J. M. \& MOSCOSO, F. América Latina Colonial. São Paulo, Unesp/CELA, 1990.

MOURA, Clovis. Rebeliôes do Scnzala. Rio de Janeiro, Conquista, 1972.

QUEIROZ, Suely R. R. Escravidão Negra em São Paulo. Rio de Janeiro, José Otympio/INL, 1977.

RADCLIFFE-BROWN, A. R. \& FORDE, Daryil (org.). Sistemas Politicos Africanos de Parentesco e Casamento. Lisboa, Fundaçăo C. Gulbenkian, 1974.

REIS, Joäo J. (org.). Escravidão \& Invenção da Libcrdade: estudos sobre o negro no Brasil. São Paulo, Brasiliense, 1986.

"O levante dos Males na Bahia: uma Interpretação Política". Estudos Económicos vol. î ( $n^{D}$ especial). Säo Paulo, IPE/USP, 1987.

- Rebeliāo Escrava no Brasil: a história do levan. tc dos Malĉs (1835). São Paulo, Brasiliense, 1986.

\& SILVA, Eduardo. Negociação e Conflito. São Paulo, Companhia das Letras, 1989. 
et alli. “Dossiê Brasil / África". Rcvista USP n" 18. 1993.

SCHWARTZ, Stuart B. "Mocambos, quilombos e Palmares: a resistência escrava no Brasil". In: Estudos Económicos vol. 17 ( $n^{2}$ especial). Sāo Paulo, IPE / USP, 1987.
SOUZA, Laura de Mello e. Desclassificados do Ouro. Rio de Janeiro, Graal, 1982.

SOW, Alpha 1. et alli.. Introduçăo à Cultura Africana. Lisboa, Ediçōes 70, 1977.

Endereço do Autor: Departamento de Antropologia e Sociologia - FICH/UFMG - Av. Antonio Carlos, 6.627 • Belo Horizonte

- Minas Gerais - Brasil - FAX (031) 448-5060 